\title{
Intermolecular Displacement of S-Bound L-Methionine on Platinum(II) by Guanosine 5'-Monophosphate: Implications for the Mechanism of Action of Anticancer Drugs
}

\author{
Kevin J. Barnham, Milos I. Djuran, Piedad del Socorro Murdoch and Peter J. Sadler* \\ Department of Chemistry, Birkbeck College, University of London, Gordon House and Christopher Ingold \\ Laboratories, 29 Gordon Square, London, UK WC1H OPP
}

NMR investigations of the kinetics and thermodynamics of the competitive binding of L-methionine (Met), L-histidine (His), and $5^{\prime}$-monophosphates of guanosine (5'-GMP), adenosine (5'-AMP), thymidine (5'-TMP) and cytidine $\left(5^{\prime}-\mathrm{CMP}\right)$ to $[\mathrm{Pt}$ (dien) $\mathrm{Cl}]+\left(\right.$ dien = 1,5-diamino-3-azapentane) in aqueous solution show that $5^{\prime}$-GMP selectively displaces S-bound Met, a finding which has implications for DNA platination by anticancer drugs in vivo.

DNA platination is thought to be a key event in the mechanism of action of platinum anticancer drugs, and there is much current interest in the mechanism of this reaction, especially in the formation of $\mathrm{Pt}-\mathrm{G}$ (guanine) adducts. ${ }^{1}$ The amino acid L-methionine (Met) is a thioether which plays an important role in the metabolism of all cells. Platinum(II) has a very high affinity for sulfur ligands and the bis-chelate$\left[\mathrm{Pt}(\text { Met }-\mathrm{H}-\mathrm{S}, \mathrm{N})_{2}\right]$ has been isolated from the urine of patients treated with the anticancer drug cisplatin \{cis$\left.\left[\mathrm{PtCl}_{2}\left(\mathrm{NH}_{3}\right)_{2}\right]\right\} .^{2}$ This complex, which is a mixture of diastereoisomers of the cis and trans isomers, ${ }^{3}$ appears to be a stable end-product of cisplatin metabolism and is unreactive towards nucleobases at neutral $\mathrm{pH} .{ }^{4}$ However we found ${ }^{5}$ that cisplatin reacts with guanosine $5^{\prime}$-monophosphate $\left(5^{\prime}\right.$-GMP) even in the presence of Met, and in order to understand the course of the latter reaction, we investigated similar reactions

Table $1 \mathrm{Kinetic}$ data for reactions of $[\mathrm{Pt}(\mathrm{dien}) \mathrm{Cl}]^{+}$and $[\mathrm{Pt}(\mathrm{dien})(\mathrm{Met}-$ $S)]^{2+}$ with $5^{\prime}-$ GMP, where $k_{2}$ is the second-order rate constant

\begin{tabular}{llll}
\hline Complex & Reactant & $\mathrm{pH}^{*}, T / \mathrm{K}$ & $10^{4} k_{2} / \mathrm{dm}^{3} \mathrm{~mol}^{-1} \mathrm{~s}^{-1}$ \\
\hline$[\mathrm{Pt}(\text { dien }) \mathrm{Cl}]^{+} 1$ & Met $^{a}$ & $3.9,300$ & 140 \\
& $\mathrm{GSMe}^{b}$ & $5.0,295$ & 330 \\
& $5^{\prime}-\mathrm{GMP}^{b}$ & $5.0,295$ & $0.62^{c}$ \\
{$\left[\mathrm{Pt}(\right.$ dien $)(\text { Met-S) }]^{2+2}$} & $5^{\prime}-\mathrm{GMP}^{a}$ & $7.0,298$ & 0.51 \\
& & $7.0,310$ & 1.66 \\
& & $7.0,318$ & 3.57 \\
\hline
\end{tabular}

“This work. ${ }^{n}$ Ref. 7 . c First-order rate constant $10^{4} k_{1} / \mathrm{s}^{-1}$.

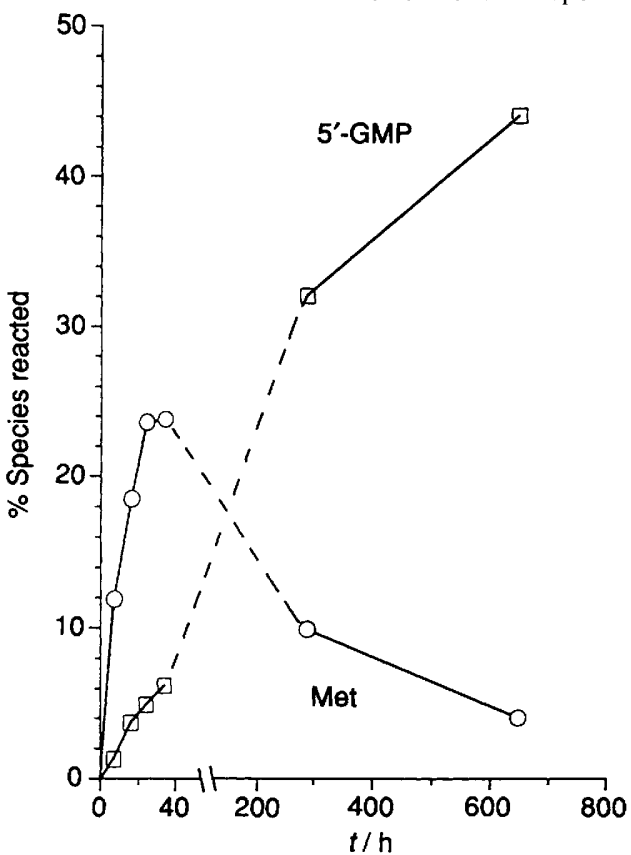

Fig. 1 Time-course of the reaction between $[\mathrm{Pt}(\text { dien }) \mathrm{Cl}]^{+} \mathbf{1}$, Met and $5^{\prime}$-GMP $(1: 2: 2 \mathrm{~mol}$ ratio). Initially there is rapid formation of $[\text { Pt(dien)(Met-S) }]^{2+} \mathbf{2}$ followed by displacement of Met by $5^{\prime}-$ GMP. In the later stages the formation of $\left[\mathrm{Pt}(\operatorname{dien})\left(5^{\prime}-\mathrm{GMP}-N^{7}\right)\right] 3$ is almost complete of $[\mathrm{Pt}($ dien $) \mathrm{Cl}]+1$. Complex 1 has the advantage that the chelated dien ligand does not readily behave as a leaving group in the presence of sulfur ligands, unlike the ammines on cisplatin. We show here that intermolecular displacement of S-bound L-methionine by $\mathrm{N}^{7}$-bound $5^{\prime}$-GMP readily occurs, and is selective in comparison with the $\mathrm{N}$ ligands of other DNA bases or L-histidine (His). These findings, together with the recent report of intramolecular displacement of a Ptbound thioether by a guanine nucleobase, ${ }^{6}$ suggest that novel routes to DNA platination by platinum anticancer drugs may exist in vivo.

First we studied the competitive reaction of $\mathbf{1}^{7 \dagger}(10$ mmol dm-3) with Met (20 mmol $\left.\mathrm{dm}^{-3}\right)$ and 5'-GMP (20 mol $\left.\mathrm{dm}^{-3}\right)$ in $\mathrm{D}_{2} \mathrm{O} \mathrm{pH}^{*} 7.2 . \neq \mathrm{In}$ the initial stages of the reaction $\left(<40 \mathrm{~h}\right.$ ), ${ }^{1} \mathrm{H}$ NMR (JEOL GX270) peaks for free Met $\left[\delta 2.136\left(\mathrm{C}^{\varepsilon} \mathrm{H}_{3}\right)\right.$ and $\left.3.869\left(\mathrm{C}^{\alpha} \mathrm{H}\right)\right]$ decreased in intensity, new peaks characteristic of $[\mathrm{Pt}(\text { dien })(\mathrm{Met}-S)]^{2+} \mathbf{2}$ appeared in the spectrum $\left[\delta 2.547\left(\mathrm{C}^{\varepsilon} \mathrm{H}_{3}\right)\right.$ and $\left.3.940\left(\mathrm{C}^{\alpha} \mathrm{H}\right)\right]$, $\S$ whereas little of the $5^{\prime}$-GMP reacted, Fig. 1 . In the later stages, the peaks for bound Met and free $5^{\prime}$-GMP $\left(\delta 8.202\right.$ for $\left.\mathrm{H}^{8}\right)$ decreased in intensity, whereas those for free Met increased in intensity, as did those assignable to bound $5^{\prime}$-GMP in $[\mathrm{Pt}$ (dien)(5'-GMP$\left.\left.N^{7}\right)\right] 3\left(\delta 8.856\right.$ for $\left.\mathrm{H}^{8}\right)$, Fig. 1. In a similar competition reaction between Met and adenosine 5'-monophosphate (5'-AMP) $\left(\mathrm{pH}^{*} 6.3\right)$, nearly all the Met reacted with 1 within $6 \mathrm{~h}$, but only $c a .2 .5 \%$ of the $5^{\prime}$-AMP had reacted after $30 \mathrm{~d}$ at ambient temperature.

In separate experiments we confirmed that the reaction of 1 with Met alone is relatively fast, and that complex 3 can be formed from complex 2 by direct displacement of coordinated Met by $5^{\prime}$-GMP. The rate of reaction of Met with 1 (half-life $2.0 \mathrm{~h}$ at $300 \mathrm{~K}$; second-order rate constant $k_{2}$, Table 1 ) is similar to that reported previously for $S$-methylglutathione (GSMe). ${ }^{7}$ The direct reaction of the Met adduct 2 with $5^{\prime}$ -

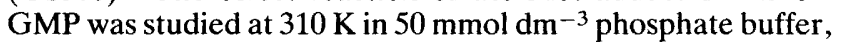
$\mathrm{pH}^{*}$ 7.0. The appropriate plot for second-order kinetics ${ }^{8}$ was

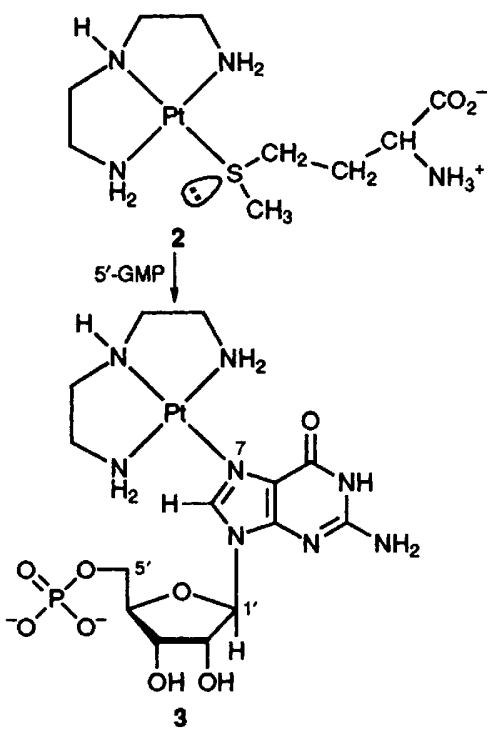


linear giving a rate constant of $1.66 \times 10^{-4} \mathrm{dm}^{3} \mathrm{~mol}^{-1} \mathrm{~s}^{-1}$ (half-life of $167 \mathrm{~h}$ ). The reaction was also followed at 298 and $318 \mathrm{~K}$, and an Eyring plot yielded values of $\Delta H^{\ddagger}$ of 73.8 $\mathrm{kJ} \mathrm{mol}^{-1}$ and $\Delta S^{\ddagger}$ of $-79.7 \mathrm{~J} \mathrm{~K}^{-1} \mathrm{~mol}^{-1}$. These values are typical of those reported previously for substitution reactions of square-planar platinum(II) complexes which occur via an associative mechanism (five-coordinate transition state) ${ }^{9}$

Reactions of 2 with nucleobases were remarkably selective for guanine. In a competitive experiment between 2 (10 mmol dm ${ }^{-3}, 50 \mathrm{mmol} \mathrm{dm}^{-3}$ phosphate buffer, $\mathrm{pH}^{*}$ 7.0) $5^{\prime}$. GMP, 5'-AMP, 5'-TMP (thymine 5'-monophosphate) and 5'CMP (cytosine $5^{\prime}$-monophosphate) $\left(10 \mathrm{mmol} \mathrm{dm}^{-3}\right.$ each), $7 \%$ of the 5'-GMP had reacted by displacing Met after $12.6 \mathrm{~h}$, but none of the other bases had reacted.

Notable also was the inability of the imidazole $\mathrm{N}$ of His to displace S-bound Met: no reaction between $2\left(10 \mathrm{~mol} \mathrm{dm}^{-3}\right.$, $50 \mathrm{mmol} \mathrm{dm}^{-3}$ phosphate buffer, $\mathrm{pH}^{*} 7$ ) and 1 mole equiv. of His was observed even after $3 \mathrm{~d}$.

Comparisons between complexes of $\mathrm{Pt}^{\mathrm{II}}$ and $\mathrm{Pd}^{\mathrm{II}}$ are of interest since $\mathrm{Pd}^{\mathrm{II}}$ analogues of $\mathrm{Pt}^{\mathrm{Il}}$ antitumour agents are usually much less active. For equimolar mixtures of $[\mathrm{Pd}($ dien $) \mathrm{Cl}]+1$, Met and 5'-GMP, only GMP adducts were detected in the NMR spectrum, whereas with Met and 5'AMP, both S-bound Met together with peaks assignable to both $\mathrm{N}^{1}$ - and $\mathrm{N}^{7}$-bound $5^{\prime}$-AMP were seen. These data are consistent with the more rapid substitution reactions of PdII compared to $\mathrm{Pt}^{\mathrm{II}}$ (often $>10^{4}$ times faster), and again with the stronger nucleophilicity of guanine compared to adenine. In the case of Pd ${ }^{I I}$, initial [Pd(dien)(Met) $]^{2+}$ may convert rapidly to $\left[\mathrm{Pd}(\right.$ dien $\left.)\left(5^{\prime}-\mathrm{GMP}-N^{7}\right)\right]$, although the reaction with GMP may also occur rapidly via aqua species. Palladium(II) binding to $\mathrm{N}^{7}$ has been established by $\mathrm{X}$-ray crystallography of $[\mathrm{Pd}($ dien $)($ guanosine $)]\left(\mathrm{ClO}_{4}\right)_{2},{ }^{10}$ and $\mathrm{Pd}^{\mathrm{II}}$ is known to bind strongly to both $\mathrm{N}^{7}$ and $\mathrm{N}^{1}$ of AMP. ${ }^{11}$

These findings have implications for the mechanism of action of platinum anticancer drugs. Sulfur ligands are generally thought to have a much higher affinity for $\mathrm{Pt}^{\mathrm{II}}$ than nitrogen ligands and to diminish the antitumour activity of platinum complexes. ${ }^{12}$ Indeed sulfur nucleophiles have been used as rescue agents to remove excess $P t$ from the body. ${ }^{13}$ The present work and that on intramolecular displacement, ${ }^{6}$ which was reported whilst this work was being written up, suggest that the binding of thioether sulfur to $\mathrm{Pt}^{\mathrm{II}}$ is reversible and could provide a novel mechanism for DNA platination. The displacement of S-bound Met by $\mathbf{N}^{7}$-bound GMP appears to be about an order of magnitude slower than the intramolecular isomerization of [Pt(dien)(guanosylhomocysteine-S)] reported by van Boom and Reedijk, ${ }^{6}$ although detailed kinetics were not determined for the latter reaction and so a proper comparison of rates is not possible.

Platinum transfer reactions to DNA bases via Met intermediates could have biological significance in cells with high concentrations of $\mathrm{Cl}^{-}$ions in their nuclei $\left(\right.$e.g. $150 \mathrm{mmol} \mathrm{dm}^{-3}$ in liver cells ${ }^{14}$ ) for which the accepted pathway of DNA platination via aqua intermediates is likely to be quenched. The GMP-Met displacement reactions are slow, but it is notable that a very slowly excreted pool of $\mathrm{Pt}$ exists in vivo after administration of cisplatin (which has a half-life of several days). ${ }^{15}$ In small cellular compartments such as the nucleus, the concentrations of the reactants may be effectively raised, so increasing the rates of the second-order substitution reactions. Also displacement reactions may be facilitated if the methionine adduct is formed not simply by Met itself, but by an accessible Met residue on a DNA-binding protein. Our finding of selective transfer to $G$ as opposed to other DNA bases, or to His which is a common residue in proteins, is notable since $\mathrm{G}$ bases are known to be major targets for $\mathrm{Pt}$ attack on DNA. ${ }^{16}$ It will be interesting to investigate the effects which Pt-bound Met and methionine-containing peptides and proteins have on the DNA sequence specificity for $G$ attack. Since monodentate S-bound Met has free amino and carboxylate groups, rapid transport mechanisms could exist for such $\mathrm{Pt}$ complexes through cellular compartments via amino acid receptors in membranes. Although thiols such as glutathione are also abundant $\mathrm{S}$-containing ligands in cells, it is notable that thioethers react faster with $[\mathrm{Pt}(\text { dien }) \mathrm{Cl}]^{+}$than thiols. ${ }^{7,17}$ Reactions between cisplatin and 5'-GMP in the presence of Met are complicated by the loss of ammine ligands, but it appears ${ }^{18}$ that displacement of S-bound Met can occur in this case also and therefore may be a general reaction available to platinum anticancer complexes.

We thank the Medical Research Council, Sybil Evans Trust, International Association for Cancer Research, the Royal Society, SERC and University of London Intercollegiate Research Service for their support for this work. We acknowledge EC support under the HCM programme (grant CHRX-CT92-0016) allowing regular scientific exchange with colleagues in Europe.

\section{Received, 22nd November 1993; Com. 3/06964H}

\section{Footnotes}

$\dagger$ The compounds $[\mathrm{Pt}(\operatorname{dien}) \mathrm{Cl}] \mathrm{Cl} \mathrm{I}$ and $\left[\mathrm{Pt}(\operatorname{dien})\left(\mathrm{NO}_{3}\right)\right] \mathrm{NO}_{3}$ were prepared as previously described. ${ }^{7}[\mathrm{Pt}(\mathrm{dien})(\mathrm{Met}-\mathrm{S})]^{2+} 2$ was prepared by mixing $\mathrm{pH} 2$ solutions (adjusted with $1 \mathrm{~mol} \mathrm{dm}^{-3} \mathrm{HNO}_{3}$ ) of $\left[\operatorname{Pt}(\right.$ dien $\left.)\left(\mathrm{NO}_{3}\right)\right] \mathrm{NO}_{3}\left(2 \mathrm{~cm}^{3}, 50 \mathrm{mmol} \mathrm{dm}-3\right)$ and $\operatorname{Met}\left(2 \mathrm{~cm}^{3}, 50 \mathrm{mmol}\right.$ $\mathrm{dm}^{-3}$ ). The reaction was carried out at low $\mathrm{pH}$ to avoid coordination of the amino group. Complete formation of the product was checked by ${ }^{1} \mathrm{H}$ NMR spectroscopy and any slight excess of one component was corrected if necessary by addition of the other component. The solution was lyophilized and the solid complex was stored at $-20^{\circ} \mathrm{C}$ and used as required.

$\$ \mathrm{pH}^{*}$ is the $\mathrm{pH}$ meter reading in $\mathrm{D}_{2} \mathrm{O}$ solution.

$\S$ The single set of peaks is indicative of rapid inversion at the chiral $S$ centre on the ${ }^{1} \mathrm{H}$ NMR time-scale consistent with monodentate S-bound Met (ref. 3).

\section{References}

1 N. Farrell, Transition Metal Complexes as Drugs and Chemotherapeutic Agents, Kluwer Academic Press, Dordrecht, 1989.

2 C. M. Riley, L. A. Sternson, A. J. Repta and S. A. Slyter, Anal. Biochem., 1983, 130, 203.

3 P. d. S. Murdoch, J. D. Ranford, P. J. Sadler and S. J. BernersPrice, Inorg. Chem., 1993, 32, 2249.

4 A. Lepre, P. d. S. Murdoch and P. J. Sadler, unpublished work.

5 M. D. Rhodes, J. D. Ranford and P. J. Sadler, in Metallothioneins: Synthesis Structure and Properties of Metallothioneins, Phytochelatins and Metal-thiolate Complexes, ed. M. J. Stillman, C. F. Shaw III and K. T. Suzuki, VCH, 1992, ch. 16, p. 423; J. D. Ranford, P. J. Sadler and R. E. Norman, Int. Chem. Congr. Pacific Basin Soc., ACS, Washington, 1989, Abstr. BIOS88.

6 S. S. G. E. van Boom and J. Reedijk, J. Chem. Soc., Chem. Commun., 1993, 1397.

7 M. I. Djuran, E. L. M. Lempers and J. Reedijk, Inorg. Chem., 1991, 30, 2648.

8 W. J. Moore, Physical Chemistry, Longman, London, 1978, ch. 9.

9 R. G. Wilkins, Kinetics and Mechanism of Reactions of Transition Metal Complexes, VCH, Weinheim, 1991, p. 235.

10 F. D. Rochon, P. C. Kong, B. Coulombe and R. Melanson, Can. J. Chem., 1980, 58, 381 .

11 R. B. Martin, ACS Symp. Ser., 1983, 208, 231.

12 N. Farrell, Transition Metal Complexes as Drugs and Chemo therapeutic Agents, Kluwer Academic Press, Dordrecht, 1989, p. 51.

13 P. C. Dedon, R. Qazi and R. F. Borch, in Biochemical Mechanisms of Platinum Antitumour Drugs, ed. D. C. H. McBrien and T. F. Slater, IRL Press, Oxford, 1986, p. 199.

14 G. Siebert, Sub.-Cell. Biochem., 1972, 1, 277.

15 A. W. Prestayko, in Cisplatin, Current status and New Developments, eds. A. W. Prestayko, S. T. Crooke and S. K. Carter, Academic Press, London, 1980, p. 2.

i6 S. E. Sherman and S. J. Lippard, Chem. Rev., 1987, 87, 1153.

17 E. L. M. Lempers, K. Inagaki and J. Reedijk, Inorg. Chim. Acta, $1988,152,201$

18 K. J. Barnham, M. I. Djuran, P. d. S. Murdoch, J. D. Ranford and P. J. Sadler, unpublished work. 